\title{
A brief review of global climate change and the public health consequences
}

\author{
Ivan Parise
}

\section{Background \\ Global climate change (GCC) will have an enormous impact on public health in the 21 st century. Evidence clearly implicates the use of fossil fuels and the resultant anthropogenic greenhouse gases as the major source of GCC.}

\section{Objectives}

This paper seeks to examine briefly the association between fossil fuels and GCC, the consequent environmental changes and the predicted public health effects.

\section{Discussion}

Complex and interrelated climate changes are forecast to present immense challenges, including increased morbidity and mortality, arising from heatwaves, extreme weather events, infectious and non-communicable diseases. The subsequent health effects, modulated by socioeconomic determinants, will be distributed inequitably primarily to vulnerable populations, largely in the tropics. A response to GCC is urgently required, involving strategies to mitigate and adapt to GCC. Not only will general practitioners be managing health conditions caused by GCC, but they are also well placed in the community to advocate for GCC mitigation.
THE CURRENT DEBATE about energy policy in Australia is firmly centred on energy costs and reliability. These are prominent issues for public health, given the morbidity and mortality related to heatwaves and cold weather, especially in disadvantaged communities. However, this policy discourse neglects the more significant health effects arising from global climate change (GCC) associated with fossil energy use.

GCC is potentially the defining challenge to public health in the 21st century. ${ }^{1}$ General practitioners (GPs), who are at the frontline of care for patients affected by GCC, must also advocate for health outcomes in the public debate concerning GCC - as the World Health Organization (WHO) asserts, 'health professionals have a major responsibility to act as advocates for health at all levels in society'. ${ }^{2}$ Consequently, this paper seeks to briefly examine the genesis of GCC and outline the predicted public health effects of GCC.

\section{The science of anthropogenic GCC}

Life on earth is dependent on naturally occurring greenhouse gases (GHGs), especially methane and carbon dioxide $\left(\mathrm{CO}_{2}\right)$, which are modulated by a complex carbon cycle. Without these GHGs trapping heat, the earth's surface temperature would be, on average, $35^{\circ} \mathrm{C}$ colder. ${ }^{3}$ The industrial world has tampered with this vital cycle by using the carbon trapped in life that has not decayed to power their industries and development. Since the 1960s, when it was estimated that doubling the $\mathrm{CO}_{2}$ content in the atmosphere would raise atmospheric average temperatures by $2^{\circ} \mathrm{C},{ }^{4}$ evidence has been accumulating linking increased
GHGs to increased global average temperatures. ${ }^{5-8}$ This century, each monthly average global land and ocean surface temperature has exceeded the average temperatures for the 20th century, ${ }^{9}$ and recent patterns of climate change are unlike past cycles. ${ }^{7,8}$

Many studies, some summarised by the Intergovernmental Panel on Climate Change (IPCC), clearly conclude that it is extremely likely that anthropogenic GHG emissions are the dominant reason for global warming since the mid20th century. ${ }^{5,6,10}$ An Australian study estimated that with anthropogenic GHGs removed, the chance of the climate pattern observed over the last 20 years occurring is $1: 100,000 .{ }^{9}$

Predictions about the future effects of GCC are more difficult, given the intricacies of local climates, the complex interrelationships of changes and the varying scenarios of GHG emission. For instance, the changes are not uniform, with land temperature found to be rising more rapidly in higher latitudes. ${ }^{11}$ Nevertheless, environmental outcomes of GCC would have substantial effects on societies, economies and health (Table 1).

\section{The public health impact of GCC}

The likely public health impact of GCC is vast; already in 2000, GCC was estimated to have caused 150,000 deaths and 5.5 million lost disability-adjusted life years (DALYs) per year. ${ }^{12}$ The full extent, summarised in Table 2, is beyond the scope of this paper and is presented in more comprehensive studies. ${ }^{1,13-15}$ Not all the changes will be adverse. Cold-related mortality and morbidity will decrease in some higher latitude populations; however, as Table 2 illustrates, this will be 
Table 1. Environmental impact of global climate change ${ }^{5}$

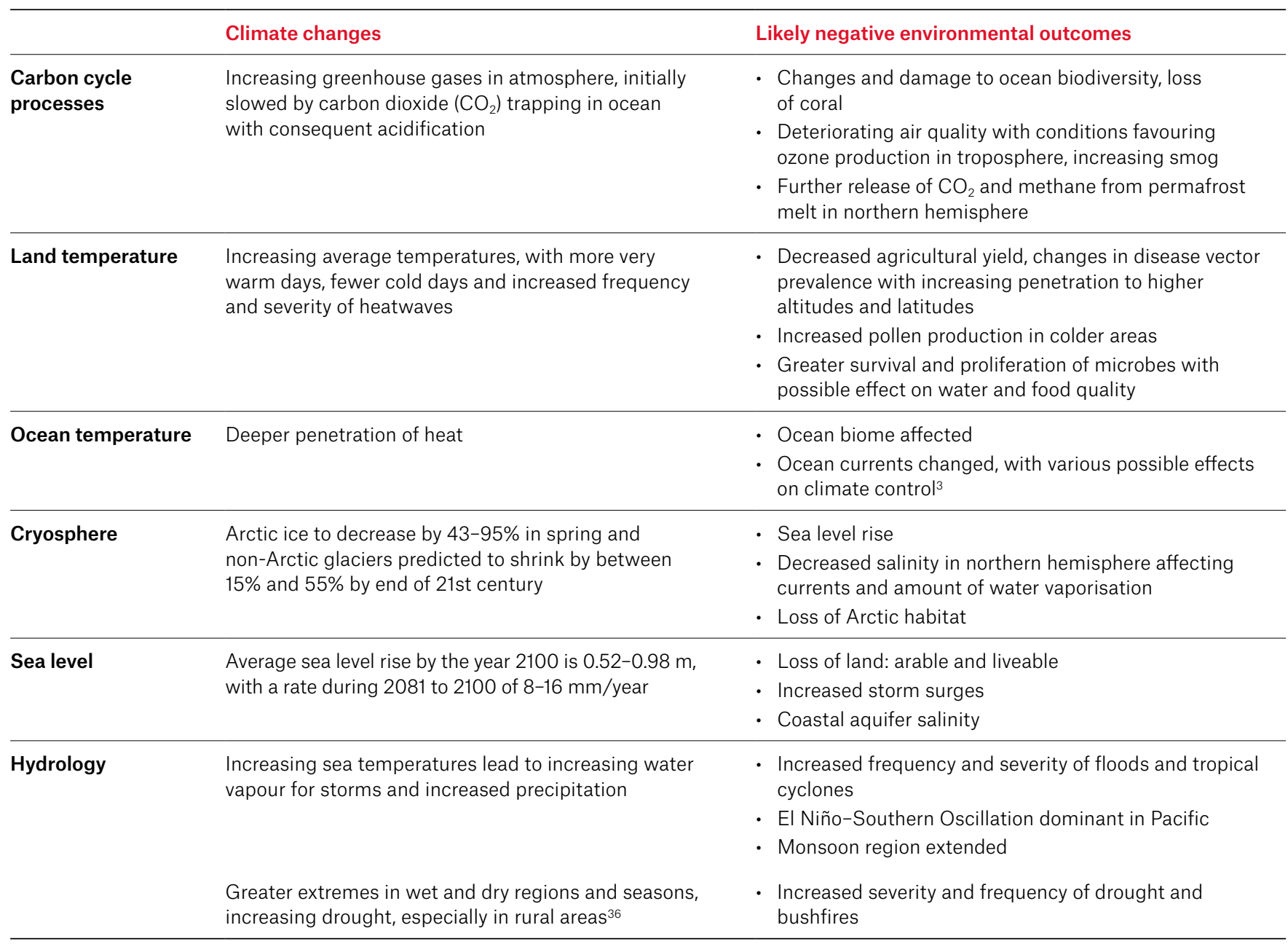

overshadowed by the numerous serious adverse health outcomes.

Predicting the future public health effects of GCC is problematic but is derived from evidence that includes observations under the adverse climatic conditions expected, and biological or statistical models. This is further complicated by the presence of other health determinants interacting with and modulating the climate change effects. For example, the trend towards urbanisation and the effects of local climates (urban heat islands) amplify the impact of heatwaves, while poverty impairs the ability of a population to adapt. ${ }^{16}$ Loss of biodiversity and predators through habitat destruction augments the effect of GCC-induced survival of vectors, such as the ticks causing Lyme disease. ${ }^{14}$

The human health effects of GCC are also interactive and more complex, as exemplified by vector ecology. Warmer temperature within the survival range of vectors will favour transmission of pathogens by increasing lifespan, reproduction, biting activity, the rate at which pathogens mature within the vector, and the latitude and altitude of subsistence. ${ }^{17}$ While increased precipitation increases the availability of breeding grounds for malaria-carrying Anopheles mosquitos, drought and alternate water storage would expand the habitat for Aedes mosquitoes that carry dengue, chikungunya and Zika. ${ }^{17-20}$ Finally, increased temperatures may increase toxicity and bioavailability of toxins that could have an impact on the host defences, and human migration will increase exposure of larger, less-immune populations. ${ }^{15,21,22}$

Despite the difficulties of modelling such changes, diseases such as malaria, dengue, yellow fever, Zika and other flaviviruses are expected to increase in incidence, especially adjacent to current endemic areas..$^{17,19,21}$ Similarly, tick, sandfly and snail survival and expanded geographic range will lead to increased incidence of tick-borne encephalitis, typhus, Lyme disease, leishmaniasis and schistosomiasis. ${ }^{17,21}$ Malaria, affecting about $50 \%$ of the world's population on a daily basis, ${ }^{23}$ is projected to increase to $60 \%$ and to favour seasonal transmission, 


\section{Table 2. Impact of global climate change (GCC) on human health}

\begin{tabular}{ll}
\hline GCC health hazards & Likely resultant adverse health outcomes \\
\hline $\begin{array}{l}\text { Extreme heat: hotter days, more } \\
\text { extreme and frequent heatwaves }\end{array}$ & $\begin{array}{l}\text { Heat-related mortality and morbidity increase } \\
\text { (mainly pre-existing cardiovascular and respiratory } \\
\text { disease), }{ }^{34,52-58} \text { especially in vulnerable populations } \\
\text { such as elderly, }{ }_{1}^{55,56} \text { children, }^{56} \text { mentally unwell }\end{array}$ \\
\hline $\begin{array}{l}\text { Extreme weather events: more } \\
\text { severe and frequent floods and } \\
\text { tropical cyclones }\end{array}$ & $\begin{array}{l}\text { Injuries and deaths, infectious diseases (eg diarrhoeal), } \\
\text { exposure to pollutants, }^{62} \text { and subsequent mental health } \\
\text { issues }^{63,64}\end{array}$
\end{tabular}

\section{Increased precipitation:}

increasing entry of human and

animal into waterways and

drinking water supplies

\section{Increase in temperature: \\ favouring pathogen proliferation}

\section{Climate changes to vector ecology: increasing proliferation, increasing biting activity, increasing latitude and altitude habitat}

Climate-related migration of reservoirs and hosts: bringing both in closer proximity

\section{Drought, crop yields and altered land availability: decreasing food security}

Air pollution: increased particulate matter (mostly not due directly to GCC but related to burning fossil fuels), ozone and allergens

\section{Changes to ocean temperature and acidity: migration and loss of fish stock}

Sea level rise: forced migration and competition for dwindling resources
Increased water-borne diseases (eg typhoid, cryptosporidiosis, campylobacter, leptospirosis) ${ }^{60,65}$

Increased food-borne illness and diarrhoeal diseases (eg salmonella, campylobacter, cholera, harmful algal blooms) $30,60,65-69$

Increased exposure and infections with arboviruses and other vector disease such as: malaria, dengue, yellow fever, Zika, Ross River fever, borreliosis, tick-borne encephalitis, typhus, leishmaniasis, filariasis and Chagas disease $\mathrm{e}^{17-20,24,27,70-73}$

Increased exposure of populations with lower immunity to disease ${ }^{71}$

Malnutrition 74,75

Respiratory tract infections and exacerbation of chronic diseases (eg cardiovascular diseases, chronic obstructive pulmonary disease and asthma) $)^{31,32,33}$

Malnutrition, especially in coastal areas of low-income countries $^{75}$

Conflict, mental health issues, health-related problems of climate asylum seekers ${ }^{15,76}$ with a larger burden from food-borne illnesses, which affected an estimated 5.4 million Australians and cost the economy $\$ 1.2$ billion in $2005 .{ }^{16}$

Non-communicable diseases, especially cardiovascular and respiratory diseases, are already leading causes of global burden of disease and are set to increase further with GCC, principally through air pollution and heatwaves. Burning fossil fuels, in addition to its role in causing GCC, is largely responsible for the health impact of ambient air pollution - an estimated 76 million DALYs globally in 2012. ${ }^{31}$ Higher ambient temperatures amplify the impact of particulate matter and increase ozone present in the troposphere. ${ }^{18,32}$ GCC will also lead to higher levels of aeroallergens, especially in more temperate regions, exacerbating asthma and allergic conditions that are already common in Australia. ${ }^{33}$

Heatwaves will become more prevalent and more extreme in Australia, with estimated summer temperatures in 2100 to peak over $50^{\circ} \mathrm{C} .{ }^{1}$ Heatwaves have already been shown to increase mortality; for instance, there was a $23 \%$ increase in non-external deaths in a Brisbane heatwave in $2004^{34}$ and a $23 \%$ increase in cardiovascular mortality due to a heatwave in Victoria in 2009. ${ }^{16}$ Given a moderate GHG emission scenario, annual mortality from excess heat in capital cities is predicted to rise by $50 \% .^{15}$

Australia is one of the most arid continents on this planet, and droughtprone areas have become even more arid since the 1970s. ${ }^{35}$ Droughts are expected to become more severe with GCC, especially in rural areas, causing adverse effects for the agricultural industry, food and water security, and mental health, especially of rural Australians. ${ }^{16}$ Accompanying this is an escalation in the severity and frequency of bushfires, again mainly in rural areas. ${ }^{15}$ The possible impact is demonstrated by the 'Black Saturday' bushfires in Victoria in 2009 where 173 people died, 2500 properties were lost and over 5000 livestock were destroyed. ${ }^{16}$ At the other extreme, there will be an increase in the frequency and magnitude of one of Australia's most common disasters - floods. ${ }^{36}$ 


\section{Inequity in GCC}

The extent of public health outcomes in Australia due to GCC pales in comparison to the expected problems that will be faced by low- and middleincome countries (LMICs). Increased vulnerability of populations in LMICs may be related to: greater habitation in high-risk areas, such as flood plains and coastal zones; ${ }^{18,37,38}$ greater exposure to rising temperatures and extreme weather events, as the majority are already in a tropical climate; ${ }^{39-41}$ greater exposure to infectious disease - for example, the per capita mortality rate from vector-borne disease is currently hundreds of times greater in LMICs when compared with high-income countries; ${ }^{17}$ and already poorer water and sanitation in LMICs and the lack of infrastructure and purchasing power leading to water scarcity ${ }^{42}$ and diminished food security. ${ }^{40}$

Poorly resourced communities are less insulated against GCC, with factors such as an inadequate public-health infrastructure; a restricted economy that will be damaged much more, proportionately, than in industrialised countries; ${ }^{43}$ fewer risk-sharing systems such as insurance; ${ }^{18}$ and governance that is often ineffective at delivering resources to prevent human suffering. ${ }^{14}$

In Australia, despite being a highincome country, much of what is problematic for LMICs is true for Aboriginal and Torres Strait Islander communities, especially in tropical Australia. Factors that increase their vulnerability to GCC are: inadequate housing; habitation in areas with vectors; decreased purchasing power; inadequate health and energy infrastructure; decreased water security; and lack of food security that contributes to an already elevated level of chronic illness. ${ }^{44,45}$ GCC will increasingly affect the health of Aboriginal and Torres Strait Islander communities and, along with historical and socioeconomic determinants, multiply the challenges to closing the Aboriginal and Torres Strait Islander health gap.

\section{Table 3. Strategies to mitigate and adapt to global climate change}

\begin{tabular}{|c|c|}
\hline \multicolumn{2}{|l|}{ Mitigation } \\
\hline Fuels and energy & $\begin{array}{l}\text { - Closing of fossil fuel energy stations } \\
\text { - International policies that set greenhouse gas and } \\
\text { temperature targets - Paris Agreement } \\
\text { - National clean energy targets } \\
\text { - Technology for carbon capture }\end{array}$ \\
\hline Land use & $\begin{array}{l}\text { - Reforestation } \\
\text { - Sustainable development }{ }^{1,13}\end{array}$ \\
\hline $\begin{array}{l}\text { Community development } \\
\text { and the built environment }\end{array}$ & $\begin{array}{l}\text { - Building low-carbon cities } \\
\text { - Informing and assisting state governments to improve public } \\
\text { transport with greater use of renewable energy and efficient } \\
\text { use of energy } \\
\text { - Informing and assisting local governments to encourage use } \\
\text { of renewable energy and more efficient use of energy } \\
\text { - Informing and assisting communities to adopt lifestyles that } \\
\text { demand less energy and use energy more efficiently } 1,13\end{array}$ \\
\hline
\end{tabular}

Adaptation

\begin{tabular}{|c|c|}
\hline Extreme weather events & $\begin{array}{l}\text { - Improved forecasting } \\
\text { - Predicting possible health outcomes } \\
\text { - Triggering effective and timely response plans, targeting } \\
\text { vulnerable populations } \\
\text { - Communicating prevention responses } \\
\text { - Updating disaster management plans }{ }^{35,77-79}\end{array}$ \\
\hline Heatwaves & $\begin{array}{l}\text { - Improved health worker training } \\
\text { - Urban planning: increasing urban green spaces, designing } \\
\text { social facilities, schools, public spaces, and public transport } \\
\text { to be more climate-responsive } \\
\text { - Public health infrastructure heatwave early warning systems } \\
\text { (HEWS), especially for the most vulnerable populations }{ }^{80-82}\end{array}$ \\
\hline Floods and storms & $\begin{array}{l}\text { - Infrastructure development such as reservoirs and floodways } \\
\text { - Development policies, zoning laws and building codes } \\
\text { accommodating for possible flooding } \\
\text { - Emergency readiness, flood forecasting, and recovery post- } \\
\text { flood including risk communication on infections, boiling } \\
\text { water, and other health issues }{ }^{77}\end{array}$ \\
\hline Food insecurity & $\begin{array}{l}\text { - Improved local ecosystem management } \\
\text { - Good governance and international mechanisms to } \\
\text { enhance food security in vulnerable populations } \\
\text { - Increased investments in rural and water infrastructure } \\
\text { - Enhanced international partnerships, especially in } \\
\text { emergency responses to food crises }\end{array}$ \\
\hline Infectious diseases & $\begin{array}{l}\text { - Improved public health capacity in all nations, especially } \\
\text { in vulnerable area } \\
\text { - Research and support for determinants of health, such } \\
\text { as education and poverty } \\
\text { - Improved surveillance and monitoring } \\
\text { - Vaccination } \\
\text { - Effective and rapid response to emerging infectious } \\
\text { diseases }\end{array}$ \\
\hline
\end{tabular}




\section{Responses to GCC}

Considering the health effects and the inequitable burden on the poorer populations, all health professionals are called to respond to GCC. This is especially true for those from high-income countries, given intuitive, justice-based and 'polluter pays' ethical frameworks. ${ }^{43}$ This must be primarily through mitigation of GCC via lower fossil fuel dependence; more efficient use of energy in industry, transport and communities; and lower carbon footprint 'built environments' (Table 3). However, the effects of GCC are already present and growing and, therefore, strategies for adaptation to GCC are crucial.

These strategies (Table 3) mainly occur upstream, though good clinical care of the chronic illnesses and infections already discussed is also required. This includes educating patients to take appropriate action during heatwaves: avoid alcohol, wear light clothing, use or visit places with air conditioning, remain well hydrated, and check on vulnerable people in their communities. ${ }^{46}$ It also involves contributing to the responses to natural disasters, such as bushfires, particularly assisting the community in recovery.

\section{Conclusion}

Internationally, in 2016, the Paris Agreement set targets for GHG emissions that hold the global average temperatures to well below $2^{\circ} \mathrm{C}$ above pre-industrial levels. ${ }^{47}$ Australia, a leading producer and one of the highest per capita consumers of fossil fuels, ${ }^{48}$ is a signatory to this Agreement. Despite this, and the Finkel Report concluding that secure energy is possible with reduced GHG emissions, ${ }^{49}$ the federal government decreased renewable energy targets in $2015^{50}$ and continues to approve new coal mines. ${ }^{51}$

GPs, as well as preventing and treating the many illnesses associated with GCC, are well placed to advocate for changes to policies that affect GCC. Individually, in community groups, or collectively through professional bodies such as The Royal Australian College of General Practitioners, Australian Medical Association, Public
Health Association of Australia, or the International Society of Doctors for the Environment, immediate action is vital. This advocacy will not only address the future public health consequences of GCC, it will also have an impact on current health issues through decreased air pollution, and improved penetration and quality of health delivery to vulnerable communities locally and globally.

\section{Author}

Ivan Parise MBBS, DRACOG, Dip Shared Care Psychiatry (Eating Disorders), MPHTM, General Practitioner, Lower Mountains Family Practice, Blaxland, NSW. ivan_parise@hotmail.com Competing interests: None.

Provenance and peer review: Not commissioned, externally peer reviewed.

\section{References}

1. Costello A, Abbas M, Allen A, et al. Managing the health effects of climate change: Lancet and University College London Institute for Global Health Commission. Lancet 2009;373(9676):1693-733. doi: 10.1016/S0140-6736(09)60935-1.

2. Nutbeam D. Health promotion glossary. Health Promot 1998;13(4):349-64. doi: 10.1093/ heapro/13.4.349.

3. Maslin M. Global warming: A very short introduction. Vol 118. 2nd edn. New York: Oxford University Press, 2004

4. Manabe S, Wetherald RT. Thermal equilibrium of the atmosphere with a given distribution of relative humidity. J Atmos Sci 1967;24(3):241-59. doi: 10.1175/1520-0469(1967)024<0241:teotaw>2.0.co;2.

5. Intergovernmental Panel on Climate Change. Fifth Assessment Report (AR5): Summary for policymakers. Geneva: Intergovernmental Panel on Climate Change, 2014. Available at www.ipcc.ch/pdf/ assessment-report/ar5/wg1/WG1AR5_SPM_FINAL. pdf [Accessed 25 July 2017].

6. Keller CF. Global warming 2007. An update to global warming: The balance of evidence and its policy implications. ScientificWorldJournal 2007;7:381-99. doi: 10.1100/tsw.2007.91.

7. Markonis Y, Koutsoyiannis D. Climatic variability over time scales spanning nine orders of magnitude: Connecting Milankovitch cycles with Hurst-Kolmogorov dynamics. Surv Geophys 2013;34(2):181-207. doi: 10.1007/s10712-012-9208-9.

8. Dansgaard W, Johnsen SJ, Clausen HB, et al. Evidence for general instability of past climate from a 250-kyr ice-core record. Nature 1993;364(6434):218.

9. Kokic $P$, Crimp $S$, Howden M. A probabilistic analysis of human influence on recent record global mean temperature changes. Clim Risk Manag 2014;3:1-12. doi: 10.1016/j.crm.2014.03.002.

10. Nordhaus WD. To slow or not to slow: The economics of the greenhouse effect. Econ J 1991;101(407):920-37. doi: doi:10.2307/2233864.

11. Easterling DR, Horton $B$, Jones PD, et al. Maximum and minimum temperature trends for the globe. Science 1997;277(5324):364-67. doi: 10.1126/ science.277.5324.364.

12. World Health Organization. The world health report 2002: Reducing risks, promoting healthy life. Geneva: World Health Organization, 2002.

13. Portier CJ, Tart KT, Carter SR, et al. A human health perspective on climate change: A report outlining the research needs on the human health effects of climate change. J Current Issues in Globalization 2013;6(4):621.
14. Myers SS, Patz JA. Emerging threats to human health from global environmental change. Ann Rev Environ Res 2009;34(1):223-52. doi: 10.1146/annurev. environ.033108.102650.

15. McMichael AJ, Woodruff RE, Hales S. Climate change and human health: Present and future risks. Lancet 2006;367(9513):859-69. doi: http://dx.doi. org/10.1016/S0140-6736(06)68079-3.

16. Australian Institute of Health and Welfare. Health and the environment: A compilation of evidence. Canberra: AlHW, 2011.

17. Campbell-Lendrum D, Manga L, Bagayoko $M$, Sommerfeld J. Climate change and vector-borne diseases: What are the implications for public health research and policy? Philos Trans R Soc Lond B Biol Sci 2015;370(1665). pii: 20130552. doi: 10.1098/ rstb.2013.0552.

18. Haines A, Kovats RS, Campbell-Lendrum D, Corvalan C. Climate change and human health: Impacts, vulnerability, and mitigation. Lancet 2006;367(9528):2101-09. doi: http://dx.doi. org/10.1016/S0140-6736(06)68933-2.

19. Paz S, Semenza JC. El Niño and climate changeContributing factors in the dispersal of Zika virus in the Americas? Lancet 2016;387(10020):745 doi: 10.1016/S0140-6736(16)00256-7.

20. Martens WJM, Jetten TH, Focks DA. Sensitivity of malaria, schistosomiasis and dengue to global warming. Climatic Change 1997;35(2):145-56. doi: 10.1023/a:1005365413932.

21. Epstein PR. Climate change and emerging infectious diseases. Microbes Infect 2001;3(9):747-54. doi: http://dx.doi.org/10.1016/S1286-4579(01)01429-0.

22. Singh BK. Climate change and human health: An environmental perspective. Climate Research 2010;41(1):41-44. doi: 10.3354/cr00839.

23. World Health Organisation. World malaria report 2016. Geneva: WHO, 2017. Available at http://apps.who.int/iris/bitstr eam/10665/252038/1/9789241511711-eng.pdf?ua=1 [Accessed 16 January 2018].

24. Martin PH, Lefebvre M. Malaria and climate: Sensitivity of malaria potential transmission to climate. Ambio 1995;24(4):200-07.

25. Centers for Disease Control and Prevention. Malaria in Italy. Atlanta, GA: CDC, 2017.

26. Centers for Disease Control and Prevention. Chikungunya in Italy. Atlanta, GA: CDC, 2017.

27. Bi P, Hiller JE, Cameron AS, Zhang Y, Givney R. Climate variability and Ross River virus infections in Riverland, South Australia, 1992-2004. Epidemiol Infect 2009;137(10):1486-93. doi: 10.1017/ S0950268809002441.

28. Epstein PR. Climate change and public health: Emerging infectious diseases. In: Cleveland $\mathrm{CJ}$, editor. Encyclopedia of Energy. Amsterdam: Elsevier, 2004.

29. Russell RC, Currie BJ, Lindsay MD, Mackenzie JS, Ritchie SA, Whelan PI. Dengue and climate change in Australia: Predictions for the future should incorporate knowledge from the past. Med J Aust 2009;190(5):265-68.

30. Zhang Y, Bi P, Hiller J. Climate variations and salmonellosis transmission in Adelaide, South Australia: A comparison between regression models. Int J Biometeorol 2008;52(3):179-87. doi: 10.1007/ s00484-007-0109-4.

31. Rao S, Pachauri S, Dentener F, et al. Better air for better health: Forging synergies in policies for energy access, climate change and air pollution. Global Environmental Change 2013;23(5):1122-30. doi: https://doi.org/10.1016/j. gloenvcha.2013.05.003.

32. Kan $\mathrm{H}$, Chen $\mathrm{R}$, Tong $\mathrm{S}$. Ambient air pollution, climate change, and population health in China. Environ Int 2012;42(Supplement C):10-19. doi: 10.1016/j. envint.2011.03.003.

33. Reid CE, Gamble JL. Aeroallergens, allergic disease, and climate change: Impacts and adaptation. EcoHealth 2009;6(3):458-70. doi: 10.1007/s10393009-0261-x. 
34. Tong S, Ren C, Becker N. Excess deaths during the 2004 heatwave in Brisbane, Australia. Int J Biometeorol 2010;54(4):393-400. doi: 10.1007/ s00484-009-0290-8.

35. Pulwarty RS, Sivakumar MVK. Information systems in a changing climate: Early warnings and drought risk management. Weather Clim Extrem 2014;3(Supplement C):14-21. doi: https://doi. org/10.1016/j.wace.2014.03.005

36. Wasko C, Sharma A. Steeper temporal distribution of rain intensity at higher temperatures within Australian storms. Nature Geoscience 2015;8(7):527. doi: 10.1038/ngeo2456.

37. Averett N. Pacific island countries and climate change: Examining associated human health vulnerabilities. Environ Health Perspect 2016;124(11):A208. doi: 10.1289/ehp.124-A208.

38. Kim R, Costello A, Campbell-Lendrum D. Climate change and health in Pacific island states. Bull World Health Organ 2015;93(12):819. doi: 10.2471/ BLT.15.166199.

39. Mendelsohn R, Morrison W, Schlesinger ME, Andronova NG. Country-specific market impacts of climate change Climatic Change 2000:45(3):55369. doi: 10.1023/A:1005598717174.

40. Admasu K, Debessa K. Action to protect human health from climate change: An African perspective. Lancet 2015;386(10006):e31-33. doi: 10.1016/S01406736(15)61139-4

41. Tol RSJ, Downing TE, Kuik OJ, Smith JB. Distributional aspects of climate change impacts. Global Environmental Change 2004;14(3):259-72 doi: https://doi.org/10.1016/j.gloenvcha.2004.04.007.

42. Ray I. Women, water, and development. Ann Rev Environ Resources 2007;32(1):421-49. doi: 10.1146/ annurev.energy.32.041806.143704.

43. Füssel HM. How inequitable is the global distribution of responsibility, capability, and vulnerability to climate change: A comprehensive indicator-based assessment. Global Environmental Change 2010;20(4):597-611. doi: 10.1016/j. gloenvcha.2010.07.009.

44. Gracey M, King M. Indigenous health part 1: Determinants and disease patterns. Lancet 2009;374(9683):65-75. doi: 10.1016/S01406736(09)60914-4.

45. King $M$, Smith A, Gracey M. Indigenous health part 2: The underlying causes of the health gap. Lancet 2009;374(9683):76-85. doi: 10.1016/S01406736(09)60827-8.

46. Hajat S, O'Connor M, Kosatsky T. Health effects of hot weather: From awareness of risk factors to effective health protection. Lancet 2010;375(9717):856-63. doi: 10.1016/S01406736(09)61711-6.

47. United Nations Framework Convention on Climate change (UNFCCC). Paris Agreement. Germany: UNFCCC, 2016. Available at http://unfccc.int/files/ essential_background/convention/application/pdf/ english_paris_agreement.pdf [Accessed 4 September 2017].

48. The World Bank. Fossil fuel energy consumption. Washington, DC: The World Bank, 2014. Available at https://data.worldbank.org/indicator/EG.USE. COMM.FO.ZS [Accessed 16 January 2017].

49. Finkel A. Independent review into the future security of the national electricity market. Canberra: Commonwealth of Australia, 2017. Available at www.environment.gov. $\mathrm{au} /$ system/files/resources/1d6b04646162-4223-ac08-3395a6b1c7fa/files/ electricity-market-review-final-report.pdf [Accessed 23 September 2017].

50. Clean Energy Council. Renewable energy target. Melbourne: Clean Energy Council, 2017. Available at www.cleanenergycouncil.org.au/ policy-advocacy/renewable-energy-target.html [Accessed 23 September 2017].

51. Chang C, AAP. Adani will begin construction of its Carmichael coal mine in October. Surry Hills, NSW: News.com.au, 29 August 2017. Available at www.news.com.au/finance/business/mining/ adani-will-begin-construction-of-its-carmichael-coalmine-in-october/news-story/87691aee29ee4368132 3503aef1f7a70 [Accessed 23 September 2017].

52. Curriero FC, Heiner KS, Samet JM, Zeger SL, Strug L, Patz JA. Temperature and mortality in 11 cities of the eastern United States. Am J Epidemiol 2002;155(1):80-87. doi: 10.1093/aje/155.1.80.

53. Huynen MM, Martens $P$, Schram D, Weijenberg MP Kunst AE. The impact of heat waves and cold spells on mortality rates in the Dutch population. Environ Health Perspect 2001;109(5):463-70.

54. Rocklöv J, Forsberg B. The effect of temperature on mortality in Stockholm 1998-2003: A study of lag structures and heatwave effects. Scand J Public Health 2008;36(5):516-23. doi: 10.1177/1403494807088458.

55. Basu R, Samet JM. Relation between elevated ambient temperature and mortality: A review of the epidemiologic evidence. Epidemiol Rev 2002;24(2):190-202. doi: 10.1093/epirev/mxf007.

56. McGeehin MA, Mirabelli M. The potential impacts of climate variability and change on temperature-related morbidity and mortality in the United States. Environ Health Perspect 2001;109(Suppl 2):185-89.

57. Perkins-Kirkpatrick SE, White CJ, Alexander LV, et al. Natural hazards in Australia: Heatwaves. Climatic Change 2016;139(1):101-14. doi: 10.1007/s10584-0161650-0.

58. Gross MH, Alexander LV, Macadam I, Green D, Evans JP. The representation of health-relevant heatwave characteristics in a Regional Climate Model ensemble for New South Wales and the Australian Capital Territory, Australia: Representing heatwaves using Regional Climate Model data. Int J Climatol 2016. doi: 10.1002/joc.4769.

59. Ledrans $M$, Pirard $P$, Tillaut $H$, et al. The heat wave of August 2003: What happened? Rev Prat 2004;54(12):1289-97.

60. Rose JB, Epstein PR, Lipp EK, Sherman BH Bernard SM, Patz JA. Climate variability and change in the United States: Potential impacts on water- and foodborne diseases caused by microbiologic agents. Environ Health Perspect 2001;109(Suppl 2):211-21.

61. Wade TJ, Lin CJ, Jagai JS, Hilborn ED. Flooding and emergency room visits for gastrointestinal illness in Massachusetts: A case-crossover study. PLoS One 2014;9(10):e110474. doi: 10.1371/journal.pone.0110474.

62. Stachel B, Götz R, Herrmann T, et al. The Elbe flood in August 2002 - Occurence of polychlorinated dibenzo-p-dioxins, polychlorinated dibenzofurans (PCDD/F) and dioxin-like PCB in suspended particulate matter (SPM), sediment and fish. Water Sci Technol 2004;50(5):309-16.

63. Reacher M, McKenzie K, Lane C, et al. Health impacts of flooding in Lewes: A comparison of reported gastrointestinal and other illness and menta health in flooded and non-flooded households. Commun Dis Public Health 2004:7(1):39-46.

64. Milojevic A, Armstrong B, Wilkinson P. Mental health impacts of flooding: A controlled interrupted time series analysis of prescribing data in England. J Epidemiol Community Health 2017;71(10):970-73. doi: 10.1136/jech-2017-208899.

65. Singh RB, Hales S, de Wet N, Raj R, Hearnden M, Weinstein $P$. The influence of climate variation and change on diarrheal disease in the Pacific Islands. Environ Health Perspect 2001;109(2):155-59. doi: 10.2307/3434769.

66. Bentham G, Langford IH. Environmental temperatures and the incidence of food poisoning in England and Wales. Int J Biometeorol 2001;45(1):2226. doi: $10.1007 / \mathrm{s} 004840000083$

67. Checkley W, Epstein LD, Gilman RH, et al. Effects of El Niño and ambient temperature on hospital admissions for diarrhoeal diseases in Peruvian children. Lancet 2000;355(9202):442-50.

68. Kovats RS, Edwards SJ, Hajat S, Armstrong BG, Ebi $\mathrm{KL}$, Menne $\mathrm{B}$. The effect of temperature on food poisoning: A time-series analysis of salmonellosis in ten European countries. Epidemiol Infect 2004;132(3):443-53.
69. Lal A, Ikeda T, French N, Baker MG, Hales S. Climate variability, weather and enteric disease incidence in New Zealand: Time series analysis. PLoS One 2013;8(12):e83484. doi: 10.1371/journal. pone.0083484.

70. Lindgren $E$, Tälleklint L, Polfeldt T. Impact of climatic change on the northern latitude limit and population density of the disease-transmitting European tick Ixodes ricinus. Environ Health Perspect 2000;108(2):119-23.

71. Hales S, Weinstein P, Souares Y, Woodward A. El Niño and the dynamics of vectorborne disease transmission. Environ Health Perspect 1999;107(2):99-102.

72. Tong S, Hu W, McMichael AJ. Climate variability and Ross River virus transmission in Townsville Region, Australia, 1985-1996. Trop Med Int Health 2004;9(2):298-304. doi: 10.1046/j.13653156.2003.01175.x.

73. Tong S, Dale P, Nicholls N, Mackenzie JS, Wolff R, McMichael AJ. Climate variability, social and environmental factors, and Ross River virus transmission: Research development and future research needs. Environ Health Perspect 2008;116(12):1591-97. doi: 10.1289/ehp.11680.

74. Parry ML, Rosenzweig C, Iglesias A, Livermore M, Fischer $\mathrm{G}$. Effects of climate change on global food production under SRES emissions and socioeconomic scenarios. Global Environmental Change 2004;14(1):53-67. doi: https://doi.org/10.1016/j. gloenvcha.2003.10.008.

75. Campbell BM, Vermeulen SJ, Aggarwal PK, et al Reducing risks to food security from climate change. Global Food Security 2016;11(Supplement C):34-43. doi: https://doi.org/10.1016/j.gfs.2016.06.002.

76. Gemenne F, Barnett J, Adger WN, Dabelko GD. Climate and security: Evidence, emerging risks, and a new agenda. Climatic Change 2014;123(1):1-9. doi: 10.1007/s10584-014-1074-7.

77. Watts N, Adger WN, Agnolucci P, et al. Health and climate change: Policy responses to protect public health. Lancet 2015;386(10006):1861-1914. doi: 10.1016/S0140-6736(15)60854-6.

78. Wilhite DA, Sivakumar MVK, Pulwarty R. Managing drought risk in a changing climate: The role of national drought policy. Weather and Climate Extremes 2014;3(Supplement C):4-13. doi: https:// doi.org/10.1016/j.wace.2014.01.002.

79. Ebi KL, Bowen K. Extreme events as sources of health vulnerability: Drought as an example. Weather and Climate Extremes 2016;11(Supplement C):95102. doi: https://doi.org/10.1016/j.wace.2015.10.001.

80. Matthies F, Menne B. Prevention and management of health hazards related to heatwaves. Int J Circumpolar Health 2009;68(1):8-12. doi: 10.3402/ ijch.v68i1.18293.

81. Pascal $M$, Laaidi $K$, Ledrans $M$, et al. France's heat health watch warning system. Int J Biometeorol 2006;50(3):144-53. doi: 10.1007/s00484-0050003-X.

82. Ebi KL, Burton I. Identifying practical adaptation options: An approach to address climate changerelated health risks. Environmental Science \& Policy 2008;11(4):359-69. doi: https://doi.org/10.1016/j. envsci.2008.02.001.

83. Rosegrant MW, Cline SA. Global food security: Challenges and policies. Science 2003;302(5652):1917-19. doi: 10.1126/ science.1092958.

84. Bezanson K, Isenman P. Scaling up nutrition: A framework for action. Food Nutr Bull 2010;31(1):178-86. doi: 10.1177/156482651003100118.

85. Keim ME. Building human resilience: The role of public health preparedness and response as an adaptation to climate change. Am J Prev Med 2008;35(5):508-16. doi: https://doi.org/10.1016/j. amepre.2008.08.022

correspondence ajgp@racgp.org.au 